\title{
OLUKORRALINE TEADMINE TÕEJÄRGSEL AJASTUL
}

\author{
RAILI MARLING
}

J uba mitu aastat kestnud vaidluses alternatiivsete faktide ja tõejärgsuse üle on nii akadeemilistes tekstides kui ka igapäevameedias nimetatud selle fenomeni üheks tekkepõhjuseks postmodernismi. Seda teevad nii erinevate valdkondade teadlased (näiteks filosoof Daniel Dennett või kognitivist Steven Pinker (2018)) kui ka sotsiaalmeedias oma poliitkorrektsusevastaste seisukohtadega kuulsust kogunud Jordan Peterson. Ka teoreetiliste vaidluste kõrgajal, 1990. aastatel, ei leitud postmodernismile ühest definitsiooni. Tänapäeval koondavad erinevad autorid selle üldnimetuse alla sotsiaalse konstruktivismi, keelelise pöörde, poststrukturalistliku ja kriitilise teooria. Huvitaval kombel sobis ja sobib postmodernism patuoinaks üldiselt kardinaalselt vastupidistel seisukohtadel olevatele vasak- ja parempoolsetele vaatlejatele. Selline üksmeel on iseenesest juba akadeemilist tähelepanu väärt. Pattude nimekirjas on enamasti välja toodud postmodernismi tõstatatud küsimus ühese ja neutraalse tõe võimatusest ja arusaam, et tõed on olukorralised, st need sõltuvad vaataja kohast ajas ja ruumis ehk sellest, kust nurgast asju vaadata ${ }^{1}$. Sellest argumendist on tuletatud järeldus, et postmodernistid on õõnestanud nende küsimustega teaduslike faktide olemuslikku ülimust ja et nende küüniliste vaadete tulemuseks ongi tänane reaalsus, kus Donald Trumpi meeskonna liige Rudy Giuliani võib teleekraanil silmagi pilgutamata öelda, et „tõde pole tõde”.

Sarnaseid süüdistusi esitati aga juba 1990. aastate nn teadussõdade ajal, mil ennast sotsiaal- ja humanitaarteadustes kinnistanud sotsiaalset konstruktivismi - arusaama, et ühiskond ja teadmised on inimeste loodud - kritiseeriti nii selle väidetava relativismi ja reaalteadustele omase objektiivsustaotluse hülgamise kui ka suisa lääne kultuuritraditsiooni ning moraalse korra õõnestamise pärast. Skandaalile lisas õli tulle paljutsiteeritud episood: kultuuriteooriale pühendatud ajakiri Social Text avaldas 1996. aastal tõsise teadusartikli pähe Alan Sokali postmodernistliku sõnavaraga täidetud paroodia. Paljude silmis oli see prohmakas ilmekas näide, et sotsiaalse konstruktivismiga seostatud teoorial tervikuna puudus teaduslik rangus. 1997. aastal avaldasid Alan Sokal ja Jean Bricmont raamatu „Impostures intellectuelles” („Intellektuaalsed teesklejad"), milles nad võtsid sihikule nende meelest postmodernismile omase episteemilise relativismi. Sellele omakorda vastasid poststrukturalistliku teooria supertähed Jacques Derrida (1997)² ja Bruno Latour (1997), kes juhtisid tähelepanu, et kriitikutel on piiratud arusaam nende tööst või üldi-

${ }^{1}$ Olukorraline tõde tuleneb mõistest olukorraline teadmine, mis on siinses käsitluses ingliskeelse termini situated knowledge tõlkevaste.

${ }^{2}$ Derrida vastus on avaldatud ka kogumikus „Papier Machine” (2001) (kirjandusprofessor Rachel Bowlby ingliskeelne tõlge ilmus 2005. aastal Stanfordi ülikooli kirjastuselt). 
semalt kriitilise ja kultuuriteooria mõtteaparatuurist. Niinimetatud teadusrealistide ja postmodernistide vaheline madin käis mitte ainult vähestele ekspertidele arusaadavate teadusajakirjade, vaid ka päevalehtede veergudel, kuni meedia sellest teemast 2000. aastate alguseks lihtsalt tüdines. Pärast 2001. aasta 11. septembrit oli üldine konsensus, et postmodernism on surnud (näiteks Kanada kirjandusteoreetik Linda Hutcheon kirjutas oma raamatu "The Politics of Postmodernism" teise väljaande järelsõnas 2002. aastal, et postmodernismi aeg on ümber saanud (2002: 166)). Meie finantssüsteem ja füüsiline julgeolek olid muutunud liiga haavatavaks, et nende üle distantseeritult ironiseerida.

Selles kirgede tormis aga jäi tähelepanuta oluline tõik: postmodernistideks nimetatud mõtlejad (kes küll ennast ise selle sildiga ei tähistanud) polnud kunagi ühtne koolkond, kes oma põhimõtteid ülikoolide auditooriumides tudengitele jutlustasid. Nad proovisid oma suhteliselt erinevate teooriatega end ümbritsevat reaalsust analüüsida. Nii Jean-François Lyotard kui ka Fredric Jameson nägid postmodernismi hiliskapitalismi loodud kultuurilise kontekstina ehk tehnoloogia- ja tarbimiskeskse, meediastunud postindustriaalse reaalsusena, milles me ka praegu veel elame. Lyotardi „Postmodernset seisundit” („La condition postmoderne”, 1979, inglise keeles ilmunud 1984) aastal 2019 üle lugedes tunduvad tema märkused komputeriseeritud ja fragmenteerunud maailma kohta ehk kõnekamatena kui ilmumise ajal. Postmodernistliku seisundi kriitiliste vaatlejate arvates muutis see uus kultuuriline reaalsus meie suhet maailmaga, sh meie võimet maailma mõista või kirjeldada. Kuna postmodernismi prognoosid on hirmutavaks reaalsuseks saanud, ei süüvi kriitikud, nagu Michiko Kakutani (2019), endi poolt postmodernistideks nimetatud autorite ideede nüanssidesse, vaid tõmbavad paralleeli nende filosoofiate ja tõejärgsuse vahele. Kui postmodernistid saavad nüüdisaja tõejärgsuse genealoogiates alati ära mainitud, siis vähem leidub viiteid kahtluse või ka otse teadmatuse tootmisele teaduslike faktide painutamise abil, mis on juba aastakümneid toimunud suurfirmade ärihuvide kaitsmiseks (vt nt Proctor 1995; Oreskes, Conway 2010). Teadlikult valede või kahtluse loomist tähistav termin agnotoloogia loodi juba 1995. aastal, aga see leiab tõejärgsust puudutavates kirjutistes palju vähem kasutamist kui postmodernism.

Kuigi fenomeni uudsust on ehk üleliia palju rõhutatud, on vaieldamatu, et tõe painutatavus on ekspertiisi devalveerumise kontekstis kulutulena levinud. Praegustes tõesõdades peetakse tihti veelahkmeks 2016. aastat, mil Oxfordi inglise keele sõnaraamat defineeris tõejärgsuse (ingl post-truth) kui objektiivsete faktide asemel emotsioonidele ja isiklikele arvamustele toetumise ning nimetas selle aasta sõnaks. Ka saksa keele ühing, Gesellschaft für deutsche Sprache, viitas samal ajal sõna postfaktisch aasta sõnaks nimetades, et üha suurem osa elanikkonnast on valmis eirama fakte ja aktsepteerima ilmseid valesid. Tõejärgsel ajastul pole otsuste tegemiseks vajalik mitte teaduslik/tõestatav tõde, vaid kõhutundel ja isiklikul kogemusel põhineva tõe väljendamine. Donald Trump võib igas lauses valetada, aga tänu otseütlevale retoorikale näib ta paljudele toetajatele ausana. Martin Montgomery (2017) Trumpi kampaaniakõnede analüüs näitabki, et Trumpi valijatele oli oluline tema tajutud autentsus, mitte tema lausungite tõesus. 
Sõjaretoorika on seega tagasi, aga rindejooned on muutunud. Enam pole näha humaniora ja realia vastandust, vaid pigem teadlaskonna ja laiema avalikkuse oma. Kui 1990. aastatel arutleti relativismi üle intellektuaalide suhteliselt kitsas ringis, siis nüüd on relativistliku retoorika omaks võtnud populismi- ja konspiratsioonialtid mõttekogukonnad. Huvitaval kombel ütles üks postmodernismi tuntumaid defineerijaid, Fredric Jameson juba 1988. aastal, et konspiratsiooniteooriad on „vaese inimese postmodernse ajastu kognitiivne kaardistamine" (Jameson 1988: 356). Kahtluse hermeneutikaks nimetatud suhtumine (Ricoeur 1977), mille üle meie, (humanitaar- ja sotsiaal)teadlased, oleme aastakümneid professionaalse pädevuse märgina uhkust tundnud, ei domineeri mitte üksnes ülikoolides, vaid kuulub teaduseeitajate ja vandenõuteoreetikute iseenesestmõistetavate mõtteharjumuste sekka. See on sundinud 1990. aastate teadussõdades vastasleerides asunud reaal- ning humanitaar- ja sotsiaalteadlasi ühist keelt leidma. Olukorda on kõnekalt kirjeldanud kriitiliste teadusuuringute (ingl critical science studies) keskne kuju, teadussõdade ajal ka Sokali ja Bricmonti sihikul olnud Bruno Latour.

Mis on kriitikast saanud, kui mu naabrid väikses Bourbonnais' külas, kus ma elan, vaatavad minu peale ülalt alla, kuna tundun olevat lootusetult naiivne, kuna ma usun, et Ühendriike ründasid terroristid? Kas te mäletate neid häid aegu, kui ülikooliprofessorid said harimata rahvale ülalt alla vaadata, sest need matsid uskusid kirikut, emadust ja õunapirukat? Asjad on sellest ajast tugevasti muutunud, vähemalt minu külas. Nüüd olen mina see, kes naiivselt usub teatud fakte, sest ma olen haritud, samal ajal teised inimesed on liiga harimatud, et olla kergeusklikud. (Latour 2004: 228, minu tõlge $-R$. M.)

Saame koos Latouriga küsida, kas lääne kultuuri suuri narratiive küsimärgistanud kultuuriteoorial on toss väljas, sest kui džinn on juba pudelist välja lastud ja tõde olukorraliseks kuulutatud, ei suuda see teooria praeguses tõejärgses kajakambris oma kui tahes vahedate analüüsidega mitte midagi korda saata. Kuna tänapäeva populistlikud poliitikud ei ole kindlasti lugenud Derrida ega Foucault' keerukaid tekste, tundub viimaste pihta kivi viskamine pigem retoorilise žestina. Samal ajal on nende sõnavaras tõesti elemente, mis nüüd populistliku retoorika ja konspiratsiooniteooria kõverpeeglist meile hirmutavalt vastu vaatavad. Peame seega endalt küsima, mida me saame täna tõe olukorralisuse defineerinud teooriate abil teha. Tööpõld on lai, sest meie ees seisavad tõeks kuulutatud väited, mis karjuvad enda tõeväärtuse uurimise järele.

Selles enesekriitilises refleksioonis on õige hetk küsida, kas tõdede olukorralisusest rääkimine tähendab, et kõik faktid on võrdsed. Praeguseks on aksiomaatiliseks muutunud arusaam, et vaatenurk on oluline element, mida peab uuritava materjali juurde asudes silmas pidama nii sotsiaal- kui ka humanitaarteadustes. Kriitilised teadusuuringud, näiteks eesti keeleski kättesaadavad Thomas Kuhni, Evelyn Fox Kelleri või Bruno Latouri tööd, on näidanud, et vaatenurk mõjutab ka teaduslike faktide tajumist, st teaduslik meetod ei ole kahjuks nii objektiivne, kui me tahaksime uskuda. Kuidas me aga tasakaalustame usku teaduslikku tõesse ning tõe olukorralisusse? Konkreetsemalt huvitab mind, milliste meetoditega saab panustada tõejärgse maa- 
ilma enda mõistmisse. Mida saab sellesse vaidlusse panustada diskursuseanalüüs kui uurimisvaldkond, mida huvitab ühiskonna konstrueerimine keeles ja keele abil?

Alustama peaks oma välja defineerimisest. Ka Eestis kasutatakse palju mõistet diskursus, aga seda defineeritakse harva. Arvestades valdkondade arvu, kus diskursuse mõistega opereeritakse, pole ime, et seda üsna erinevalt mõistetakse (Mills 2004: 1). Ka humanitaarias on diskursusel kaks erinevat sugupuud ning sellel pärilusliinil on tõejärgsuse kontekstis ehk oluline roll. Eesti intellektuaalsel maastikul on diskursuse mõiste kinnistunud ideedeajaloolase Michel Foucault' tööde kaudu, kes on omakorda üks postmodernismiga seostatud mõtlejatest (ise on ta küll selle sildi otseselt vaidlustanud). Foucault (1972: 49) nimetas diskursusteks praktikaid, mis vormivad seda, millest nad räägivad. Foucault' ideed saab asetada laiemasse keelelise pöörde konteksti, mille kohaselt keel kujundab meie reaalsust ning muu hulgas arusaama tõest (Piirimäe 2008: 592). Kuna tähelepanu keskmesse liikus representeerimine keele abil ja keeles, siis tunti keelelise pöörde kontekstis üha enam huvi keele piire loova ja sildistava funktsiooni vastu, samuti keele ja võimu omavaheliste suhete vastu. Huvi peamine objekt polnud aga keel, vaid ühiskond ja selle mõttestruktuurid, mis tegid mõned lausungid võimalikuks ja võimukaks, teised mitte. Kõige tuntum arvamus selles kontekstis on ehk Foucault' (1972: 32) mõtteavaldus, et millelgi pole tähendust väljaspool diskursust.

Laiemalt saab seda suunda seostada ka poststrukturalistlikeks nimetatud mõtlejatega, kes ise ehk konkreetselt diskursuse mõistet ei kasutagi, kuid kes jagavad huvi ideede ja tõdede konstrueerituse vastu. Nende mõtlejate ringi võib sildistada näiteks prantsuse kontekstis käibel oleva mõistega la French theory, mis rõhutab mõttekoolkonna kujunemist ideede liikumise toel ingliskeelse, valdavalt ameerika, ja prantsuse kultuurikonteksti vahel. Prantsuskeelses kontekstis poststrukturalismi mõistet ei kasutatud; pigem peeti neid mõtlejaid lihtsalt kriitilisteks intellektuaalideks (Angermüller 2015: 39). Mainitud teooriate rändamine väärib pikemat läbikirjutamist kusagil mujal. Eesti keeles on sellest mõttekoolkonnast kättesaadavad Foucault', aga ka Jacques Derrida, Gilles Deleuze’i ja Jean Baudrillardi tööd.

Teisalt on juba 1950. aastatest olemas keeleteaduse alavaldkond, kus uuritakse samuti diskursust, käsitledes seda mõnevõrra teisiti - üldistatult kui konteksti asutatud keelt (Brown, Yule 1983). Siingi on ridamisi definitsioone, aga üldiselt jagab enamik diskursuseuurijaid arusaama, et erinevaid keeleteaduslikke meetodeid kasutades uuritakse tekstide keelelist ja struktuurilist külge ning ka esinemiskonteksti. Nt Cambridge’i ülikooli kirjastuse lingvistikaõpikute sarjas ilmunud diskursuseanalüüsile pühendatud raamatu alguses toovad autorid välja, et diskursus on kasutuses oleva keele analüüs, mis nõuab lisaks keelevormide kirjeldamisele nende funktsiooni analüüsi (Brown, Yule 1983: 1). Eestis ongi diskursuseanalüüs olnud valdavalt lingvistiline tekstianalüüs (näiteks Reet Kasiku ja Krista Kerge loodud tekstiuurimise koolkonnas, mille kogumikesarjal on kõnekas nimi „Tekstid ja taustad"). Selgelt empiirilise fookusega keeleteaduslikul analüüsil on abstraktse poststrukturalistliku mõttega näiliselt vähe kokkupuutepunkte. 
Kui uurime kasutuses olevat keelt, põrkume paratamatult vajadusega määratleda, kuidas me seda kasutuskonteksti uurime. Juba diskursuse mõiste juurutaja keeleteaduses, ameerika lingvist Zellig Harris, kirjutas 1952. aastal:

Seostatud diskursus eksisteerib mingis konkreetses situatsioonis - olgu siis jutt inimesest, kes räägib, või vestlusest või kellestki, kes iganes pikema perioodi vältel maha istub ja mingit konkreetset kirjanduslikku või teaduslikku traditsiooni järgides konkreetset tüüpi raamatut kirjutab. (Harris 1952: 3 , minu tõlge $-R . M$.)

Raskused tekivadki valdavalt küsimusest, kui laialt seda konteksti vaadata: kas piirduda ainult lausungikontekstiga konkreetses tekstis või peaks kaasama ka kultuurilist ja ühiskondlikku konteksti. Kui teha viimast, siis kust läheb piir olulise ja ebaolulise info vahel?

Viimane küsimus lähendab oma juurtelt muidu keeleteadusesse paigutuvaid diskursuseuurijaid diskursuseteoreetikutele, kuigi erinevate artiklite viiteaparatuuri kontrollides on näha, et keeleteadlased võivad küll Foucault'le viidata, kuid tema metoodiliselt väga teiselaadset lähenemist nad sisuliselt ei kasuta. Pigem on tema nime tekstile lisamine viisakas kummardus kui sisuline metodoloogiline solidaarsus. Tuntud prantsuse diskursuseuurija Dominique Maingueneau (2001) sõnutsi oleks „selge eksitus” pidada Foucault'd diskursuseanalüüsi loojaks, kuna tema ambitsioonid selles osas piirdusid vaid „irooniaga, millest ei maksa end petta lasta” (tsiteeritud Käsper, Marling 2018: 733). Foucault, keda huvitas 1960. aastatel strukturalistliku keeleteaduse potentsiaal, flirdib keeleteadusliku terminoloogiaga, kuid ei rakenda seda oma töödes sisuliselt. Keelekeskses diskursuseanalüüsis on tunda kannatamatust metoodika mõttes pigem filosoofidele lähedaste teoreetikute suhtes, kes opereerivad heal juhul üksiknäidetega ning ei rakenda süsteemseid keeleteaduslikke meetodeid ei oma korpuste koostamisel ega nende analüüsil. Seega on diskursuseteoreetikute ja -analüüsijate vahel jätkuvalt tajutav koolkondlik erinevus.

Samal ajal on keeleteadlased püüdnud arendada metoodikaid, mis võimaldaksid süsteemselt uurida ka keelekasutust tahes-tahtmata mõjutavat ühiskondlikku konteksti, sh ühiskonnas levinud mõttemalle ja väärtushinnanguid. See idee on olnud Harrisest tuleneva formaal-keeleteadusliku impulsi kõrval diskursuseanalüüsiski esil (Eestis pea tundmatu) Michel Pêcheux' töödes alates 1960. aastatest. Pêcheux proovis keele ühiskondlikule aspektile keskendudes arendada „automaatse ideoloogia paljastamise masina” (Käsper, Marling 2018: 733). Keel pole tema silmis mingi puhtaks pestud aken, läbi mille saame maailma või ennast vaadata. Pigem on tegu läbipaistmatu, märkidest koosneva pinnaga, mis vajab lahtikodeerimist, milleks on aga vaja keeleliste vormide süsteemset analüüsi ja teadlikkust ümbritsevast sotsiaalsest reaalsusest (Angermüller 2018a: 3). Pêcheux' töödest erinev, teist arenguliini pidi M. A. K. Halliday süsteemfunktsionaalsest lingvistikast välja kasvanud ingliskeelne kriitilise diskursuseanalüüsi koolkond on pead murdnud, kuidas ühiskondliku konteksti analüüsi ja kriitikat sujuvalt keelelise kirjeldusega sobitada. Üheks lahenduseks, mille koolkonna esindajana pakkus esmalt välja briti keeleteadlane Norman Fairclough (1989), on lähtuda analüüsis keeleliste 
valikute objektiivsest kirjeldamisest, kuid lisada sellele etapile diskursiivsete protsesside tõlgendus ja sotsiaalsete protsesside selgitus. Keskendumine süsteemselt analüüsitud keelematerjalile (mitte juhuslikult valitud mahlakatele näidetele) lubab kriitilisel diskursuseanalüüsil ning ka teistel lingvistilistel diskursuseanalüüsi meetoditel tõestada teatud mõttemallide olemasolu mingis kultuuriruumis kasutatavas keeles ja tekstides. Fairclough (1995: 142-149) on näiteks 1990. aastate alguse Ühendkuningriigi ülikoolide töökuulutusi keeleliselt analüüsides näidanud turuloogika tungimist akadeemilisse keelekasutusse ja sellega edestanud viimase kümne aasta analüüse neoliberaalse ratsionaalsuse levimisest paljudesse eluvaldkondadesse (vt nt Brown 2015).

Eesti keeles on kriitilise diskursuseanalüüsi näidetest kättesaadav Teun van Dijki (2005) raamat „Ideoloogia”, kus van Dijk lisab ideoloogia uurimises kesksele sotsiaalsete struktuuride analüüsile ka sotsiaalse kognitsiooni ja diskursuse mõõtme, et näidata, kuidas ideoloogiad omaks võetakse. Ta püüab pakkuda teoreetilist alust ideoloogiate, nt rassismi, uurimiseks erinevates distsipliinides. Raamatu viimasest peatükist leiame ka konkreetseid keelelise analüüsi näiteid, kuigi need pole nii detailsed kui kriitilise diskursuseanalüüsi juhtumianalüüsides tavapärane.

Tänapäeval pole aga isegi mitte kriitiline diskursuseanalüüs ühtne meetod, vaid valdkond, kus teksti ja seda ümbritseva konteksti vastastikuste mõjutuste uurimiseks rakendatakse erinevaid, nii kvalitatiivseid kui ka kvantitatiivseid meetodeid. Meetodite paljusus näitab, et ühest ja kõiki rahuldavat meetodit pole nende kahe poole uurimiseks lihtsalt leitud. Eriti keerukaks muudab asja see, et mida kaugemale liigume konkreetsetest lausungitest, seda enam nõuab diskursus kiretu kirjelduse kõrvale tõlgendusi, mis on aga paratamatult olukorralised. Paljude keeleteadlaste jaoks on tõlgenduslikule pinnale astumine lingvistika baasarusaamade tõttu distsiplinaarselt keerukas. Seega otsitaksegi just sellel pinnal abi diskursuseteooria erinevatelt koolkondadelt (Foucault, Ernesto Laclau, Chantal Mouffe jne, vt nt Jørgensen, Phillips 2002), kuigi näib, et teoreetiline raamistik ja empiiriline analüüs jäävad paljudes keelelistes analüüsides (nt Fairclough'l) eraldi seisvaks.

Seega tuleb tõe küsimärgistamise mõistmise protsessis vahet teha kahel diskursuse mõistega opereerival humanitaaria alavaldkonnal, mis huvituvad samadest asjadest, kuid lähenevad neile erineval moel. Kahel suunal kontinentaalfilosoofiast tuleneval võimuanalüüsil ja positivistliku alusega keeleteadusel - on selged puutepunktid ja on autoreid, kes liiguvad suundade vahelgi, kuid see on pigem erand (sotsiaalteadustes ei võeta diskursuse keeleteaduslikku elementi ehk sama tõsiselt ja seal pole veelahe sama tuntav). Käesoleva debati kontekstis on teoreetilise ja keelekeskse diskursuseanalüüsi erisus aga tähendusrikas. Avalikes debattides on nahutada saanud abstraktne teooria ning piisavalt tihti pole küsitud, kas sellele ei saaks veenvust lisada empiirilise keeleteadusliku metoodika abil.

Üheks praeguse kriisi tunnuseks on vähemalt osaliselt kriitilise teooria väsimine, sest teksti varjatud tähendusi otsiv analüütiline meetod ja kahtluse hermeneutika pole suutnud tõejärgsuse analüüsiks uudseid ja tõhusaid lähenemisi välja pakkuda. Ingliskeelne kirjandusteooria on viimasel kümnel aastal muutunud üldse tagasihoidlikumaks. Lääne mõttetraditsiooni revideerimise ja kaanoni kõigutamise asemel näeme postkriitiliste kirjeldavate 
ja formalistlike meetodite buumi (vt nt Anker, Felski 2017). Selles laiemas raamistikus tuleks oma teoreetiline tööriistakast läbi vaadata ka diskursuseanalüüsiga tegelejatel ja mõelda, milliste meetoditega saab toimetada maailmas, kus üldsus on igal juhul uurijast paranoilisem, sh uurija enda suhtes. Kuna teooria tuleviku üle mõtiskleb käesolevas Keele ja Kirjanduse numbris Daniele Monticelli, keskendun mina pigem rakenduslikumale küsimusele: kas keelekeskne diskursuseanalüüs on tõhus abivahend, mis aitaks meil mõista tõejärgsust kui ühte olukorralise teadmise vormi?

Diskursuseuurijate jaoks on ilmne, et diskursused on alati olukorralised, sest nad pärinevad kusagilt (Block 2019: 10) ja eksisteerivad koosmõjus teiste neid ümbritsevate ja nendega konkureerivate diskursustega. Kunagi ei eksisteeri vaid ühte diskursust, olgu domineeriv diskursus nii ülekaalukas kui tahes. Ka kõige suletumas ühiskonnas toimuvad diskursuste kokkupõrked (mõelgem kas või nõukogude aja kogemusele Eestis, kus ametlik diskursus tekitas endale elujõulisi vastudiskursusi). Tänapäeval toimuvad diskursiivsed võitlused muuhulgas tõe tähenduse üle. On erinevaid tõdesid, alustades religioossetest ilmutatud tõdedest ja lõpetades empiirilise tõega (Baggini 2017). Ka sageli kriitika objektiks olev Foucault ei eitanud tõdede olemasolu ega proovinud konkreetsete diskursuste tõeväärtust kummutada (Prozorov 2019). Tõe ja demokraatia teemal on viljakas lugeda Foucault' viimaseid loenguid (Foucault 2010, 2011).

Diskursuseanalüüs ei eita, et eksisteerib maailm, mis pole diskursiivselt konstrueeritud. Diskursused aga vahendavad meie teadmisi selle maailma kohta. Diskursuseanalüüs ei ole sünonüümne dekonstruktsiooni ega eriti selle lihtsustatud tõlgendustega. Teisalt ei saa me ühiskondades elavate keelekasutajatena kõike, mis meie keeles toimub, seletada vaid objektiivsete keelereeglitega. Ühiskond ja selle väärtushinnangud mõjutavad keelt ja seda, kuidas me selle abil maailma kujutame. Keelt uurides saame ligi vähemalt osale ühiskonna vaikimisi omaks võetud tõekspidamistest.

Toetun järgnevas saksa-prantsuse diskursuseuurija Johannes Angermülleri väljapakutud diskursuseanalüüsi programmile. Nii diskursuseteooria kui ka diskursuseanalüüs on huvitunud sellest, kuidas tõdesid mingi diskursiivse kogukonna keelekasutuse abil luuakse ja kinnistatakse (Angermüller 2018a: 4). Väga tüüpiliselt küsitakse, kuidas diskursiivsed praktikad kujutavad sotsiaalset reaalsust, aga ka kuidas nad kujutamise kaudu seda kujundavad (Foucault 1972; Fairclough 1992 jne). Ent Angermüller (2018a: 4) rõhutab, et diskursuseuurijad räägivad erinevatest sotsiaalsetest reaalsustest, mis võivad omavahel vastuolus olla. Diskursuseanalüüsija ei pea tõenäoliselt aktsepteeritavaks seda sotsiaalset reaalsust, mida usub lapiku maa teooria toetaja. Seda reaalsust peavad uurijad diskursiivselt konstrueerituks (potentsiaalselt vääraks), aga uurija enda reaalsust samamoodi diskursiivselt konstrueerituks ilmtingimata ei peeta. Kriitilise diskursuseanalüüsi traditsioonis vaatlevad uurijad teatud fenomene sotsiaalsete probleemidena, selle asemel et tuvastada, mida mingi kogukonna liikmed peavad sotsiaalseks probleemiks. Diskursuseanalüüs toetub sellisel juhul uurija enda arusaamale näiteks sellest, mis on sotsiaalne ebavõrdsus. Uurija vaatenurk väidetakse seega olevat objektiivsem kui tema uuritavate inimeste oma. Selline asümmeetria on epistemoloogiliselt nõrk. Just sellest tulenebki oht, et näiteks lapiku maa teooria 
toetaja kasutab sama argumenti ja nimetab teadust, elitaarset kõrgharidust ja traditsioonilist meediat sotsiaalselt konstrueerituks ja ennast analüüsimist mittevajavalt tõepositsioonilt, n-ö terve mõistuse vaatenurgast rääkijaks.

Diskursuseuurijatel pole ühiskonna vaatlemiseks mingit privilegeeritud positsiooni, mis on teiste omast objektiivsem. Just seetõttu on metodoloogia küsimustes diskursuseanalüüsiga tihti vaielnud vestlusanalüüs rõhutanud vajadust vaadata ainult seda, mida suhtluses osalejad teevad, püüdmata tuvastada osalejate eest varjatuks jäävaid allhoovusi, mis võivad nende käitumist mõjutada. See omakorda tekitab väga erineva arusaama sellest, kellel on õigus kogemust kommenteerida: kas kogejal või kriitilise aparatuuriga varustatud uurijal, kes näeb tekstist ja samamoodi ka uuritavast läbi (Angermüller 2018a: 4). Angermüllerile (2018a: 5) teeb muret, et ühelt poolt rõhutab diskursuseanalüüs, et diskursus kujundab ühiskondlikku konteksti, mitte lihtsalt ei kujuta seda. Teisalt kajab aga paljudest diskursuseuuringutest läbi arusaam, et on siiski mingid ühiskondlikud formatsioonid, nt võim ja ebavõrdsus, mis ei ole pelgalt diskursiivsed konstruktsioonid. Nagu uurija positsiooni puhul, tekib siingi küsimus võimalikest topeltstandarditest.

Selle vastuolu najal pakub Angermüller välja oma programmi, mis on mõjutatud teaduse ja tehnoloogia uuringutest (ingl science and technology studies), eriti David Bloori (1991) tööst. Angermülleri järgi on diskursus olukorraline praktika, milles diskursiivsete kogukondade liikmed keeleliselt tõdesid loovad ja lammutavad. Ühiskonnast mõjutamatu tõe leidmise asemel pakub ta välja konkureerivate tõdede loomise reflektiivse uurimise (Angermüller 2018a: 5). Samal ajal ei väida Angermüller, et reaalseks ja tõeseks peetav on vaid diskursiivsete praktikate loodud; keelelis-diskursiivsete praktikate kõrval eksisteerivad ka mittekeelelised. Angermüller rõhutab, et tõesed ja väärad ideed eksisteerivad diskursiivsete praktikatena kõrvuti. Siiani on diskursuseanalüüs üldiselt püüdnud maski peast rebida enda silmis vääraks peetavatel tõdedel. Angermüller arvab, et peaksime samade teoreetiliste ja metoodiliste vahenditega vaatlema seda, mis on meie vaatenurgast hinnatuna tõene ja mis väär. Ta on oma ideestikust lähtuvalt sõnastanud kolm põhimõtet (Angermüller 2018a: 6):

1. Tegurite eripalgelisus. Reaalsuse konstrueerimiseks kasutatakse eripalgelisi diskursiivseid, aga ka mittediskursiivseid vahendeid, st oluline on vaadata enamat kui vaid keelt. Diskursuses osalejad kasutavad tähenduste ja tõdede loomiseks sotsiaalseid, keelelisi ja füüsilisi vahendeid. Samuti ei eeldata, et tõde peegeldab mingit üht võimustruktuuri.

2. Mitmeperspektiivsus. Analüüsija peaks vaates ühiskonnale hoiduma n-ö jumalaperspektiivist. Selle asemel et otsustada, mis on üks ja ainus tõde, tuleb analüüsida erinevaid konkureerivaid tõdesid ja seda, kuidas need ja nende tõeväärtus on konstrueeritud nii diskursuses kui ka väljaspool seda. Kõik ideed pole siiski võrdsed, kuna jätkuvalt saab eristada fakte ja teadmiste saamiseks kasutatavaid meetodeid.

3. Kriitiline refleksiivsus. Diskursuseanalüüsija peab vaatlema ka oma tegevust kui uuritavate diskursiivsete objektide osa, sest teaduslik diskursus ei ole mitteteaduslikest praktikatest, sh poliitikast, hermeetiliselt eraldatud.

Kuigi Angermüller viitab vaid teaduse ja tehnoloogia uuringute tugevale programmile, saab tema tekstist välja lugeda toetumist pehmele relativismile 
(kuigi ta vastavat terminoloogiat ei kasuta). Selline pehme relativism aktsepteerib episteemilist relativismi (mille kohaselt diskursused kasvavad välja konkreetsest kontekstist), kuigi mitte arusaama, et kõik diskursused pakuvad reaalsusest sama valiidset representatsiooni, kuna igas kontekstis on olemas faktide ja arvamuste eristamise kriteeriumid (Jørgensen, Phillips 2002: 196197).

Angermülleri (2018a: 6) arvates peaks diskursuseanalüüs keskenduma diskursiivsele praktikale, mille abil mingis diskursiivses kogukonnas aja jooksul tõdesid konstrueeritakse. Teaduslikus kogukonnas on kehtestatud kvaliteedistandardid ja meetodid, mis aitavad vahet teha tugevamate ja nõrgemate väidete vahel, paremini ja halvemini põhistatud tõdede vahel. Me peame aga sellest kõigest rääkima, mitte eeldama, et meie eeldused on vaikimisi kõigile samamoodi arusaadavad. Angermüller (2018b: 419-423) näitlikustab ühes oma analüüsis, kuidas nii libauudiste kui ka akadeemiliste staaride loomine järgib sama diskursiivse kapitali kogumise loogikat. Nii libauudiste najal tippu tõusvad poliitikud kui ka akadeemilised staarid tekivad diskursiivse kogukonna liikmete tegevuste ja diskursiivsete protsesside tulemusena: kui „Trumpi” kui nähtust kujundavad tema loendamatud toetajad ja vastased oma erinevate väljaütlemistega, siis akadeemilisi tähti loovad samamoodi lugematud vähe(m)tuntud teadlased oma tsiteeringutega. Angermülleri analüüs näitab kahte väga erinevat tõde tootvate diskursiivsete kogukondade ja protsesside toimimist, kuid ei paku empiirilise korpuse kvalitatiivset või kvantitatiivset analüüsi. Inglise keeles on kirjutatud juba mitmeid lingvistilise diskursuseanalüüsi võimalusi kasutavaid magistritöid, mis vaatlevad tõejärgse diskursiivse ruumi kujundamist.

Selleks et tõejärgsust kriitiliselt küsimärgistada, on vaja määratleda ja kriitiliselt kompida ka tõde. Me peame eelkõige suunama ennast kriitilisele refleksioonile, võrdlusele ja esitama küsimusi faktide allikate ja nende leidmiseks kasutatud meetodite kohta. Sotsiaalteadustes on kvalitatiivsete meetodite kasutamisel tavapärane, et uurija arutleb enda positsiooni ja selle mõju üle materjalile. Seda põhimõtet mainivad ka mitmed kriitilised diskursuseanalüüsijad, kuigi üsna möödaminnes ja rakendamata seda alati omaenda arusaamale ühiskonna võimustruktuuridest (nt Fairclough, Chouliaraki 1999; Wodak 2013). Veel üheks võimaluseks on üha suurem meetodite kombineerimine, et jõuda empiirilise materjali mitmetahulisema analüüsini (Rheindorf 2019).

Seda on kõike diskursuseuuringutes tehtud ja just praegu, kui meil on kriitilist mõtlemist vaja, ei tohiks minema visata selle lähenemise väljatöötatud olukorralise teadmise refleksiivse uurimise tööriistakasti. Eriti just empiirilise materjali analüüsiks erinevaid meetodeid arendanud diskursuseanalüüs on selles olukorras ehk väärtuslikum kui kunagi varem. Oleks väär diskursuseteoreetikute liialdatud patud nuhelda diskursuseanalüüsijate kätte ja loobuda kasulikust meetodipagasist, mis võimaldab vaadelda objektiivselt kirjeldatavat keelelist materjali ning kommenteerida seda erinevate teoreetiliste lähtekohtade valguses. Kui me soovime mõista, miks tõejärgsus on paljudele nii inspireeriv, peame suutma seda fenomeni erinevates kasutuskontekstides kirjeldada, ja keeleteadus, nii kvalitatiivne kui ka kvantitatiivne, pakub meile selleks väga erinevaid võimalusi. Diskursuseanalüüs võiks olla tõhus vahend 
ja meie kohustus on oma metoodika üle reflekteerida ning seda täpsemaks sõnastada, et sellest ei saaks paralleeli üha resistentsemaks muutunud bakterite ees võimetutele antibiootikumidele.

\section{Kirjandus}

Angermüller, Johannes 2015. Why There Is No Poststructuralism in France. The Making of an Intellectual Generation. London: Bloomsbury.

Ang ermüller, Johannes 2018a. Truth after post-truth: For a strong programme in discourse studies. - Palgrave Communications, $\mathrm{kd} \mathrm{4,} \mathrm{nr} 30$, lk 1-8.

Anger mülle r, Johannes 2018b. Accumulating discursive capital, valuating subject positions. From Marx to Foucault. - Critical Discourse Studies, kd 15, nr 4, lk 414-425.

Anker, Elizabeth S., Felski, Rita (toim) 2017. Critique and Postcritique. Durham: Duke University Press.

B aggi ni, Julian 2017. A Short History of Truth. London: Quercus.

Block, David 2019. Post Truth and Political Discourse. Cham: Palgrave Macmillan.

B l o o r, David 1991. Knowledge and Social Imagery. Second edition. Chicago: University of Chicago Press.

B rown, Wendy 2015. Undoing the Demos. Neoliberalism's Stealth Revolution. New York: Zone Books.

Brown, Gillian, Yule, George 1983. Discourse Analysis. Cambridge: Cambridge University Press.

De r r i d a, Jacques 1997. Sokal et Bricmont ne sont pas sérieux. - Le Monde 20. XI.

F a ir clough, Norman 1989. Language and Power. London: Longman.

F airclough, Norman 1992. Discourse and Social Change. Cambridge-Malden: Polity Press.

Fairclough, Norman 1995. Critical Discourse Analysis. The Critical Study of Language. London: Longman.

Fairclough, Norman, Chouliaraki, Lilie 1999. Discourse in Late Modernity. Edinburgh: Edinburgh University Press.

F ouc a u lt, Michel 1972. The Archeology of Knowledge and the Discourse on Language. Tlk A. M. Sheridan Smith. New York: Pantheon Books.

Foucault, Michel 2010 The Government of Self and Others. Lectures at the Collège de France 1982-1983. Tlk Graham Burchell. Basingstoke: Palgrave.

F o u ca ult, Michel 2011. The Courage of Truth. Lectures at the Collège de France 1983-1984. Tlk Graham Burchell. Basingstoke: Palgrave.

Har r i s, Zellig S. 1952. Discourse analysis. - Language, kd 28, nr 1, lk 1-30.

Hutcheon, Linda 2002. The Politics of Postmodernism. 2nd edition. London: Routledge.

J a m e s o n, Fredric 1988. Cognitive mapping. - Marxism and the Interpretation of Culture. Toim Cary Nelson, Lawrence Grossberg. Urbana: University of Illinois Press, lk 347-357.

Jørgensen, Marianne W., Phillips, Louise J. 2002. Discourse Analysis as Theory and Method. London: SAGE Publications. 
Kakutani, Michiko 2019. The Death of Truth. Notes on Falsehood in the Age of Trump. New York: Random House.

Käsper, Marge, Marling, Raili 2018. Diskursuseanalüüsi muutuv suhe kvantifitseerimisega inglis- ja prantsuskeelses traditsioonis. - Keel ja Kirjandus, nr 8-9, lk 728-746.

Latour, Bruno 1997. Y a-t-il une science après la Guerre Froide? - Le Monde 18. I.

Lat o ur, Bruno 2004. Why has critique run out of steam? From matters of fact to matters of concern. - Critical Inquiry, nr 30, lk 225-248.

Lyotard, Jean-François 1984. The Postmodern Condition: A Report on Knowlegde. Tlk Geoff Bennington, Brian Massumi. Manchester: Manchester University Press.

Mainguen ea u, Dominique 2001. Archéologie et analyse du discours. - Sociologie du travail, kd 7, nr 5. - http://www.revue-texto.net/Reperes/Themes/Maingueneau_Archeologie.html

Mills, Sara 2004. Discourse. London-New York: Routledge.

Montgom ery, Martin 2017. Post-truth politics? Authenticity, populism and the electoral discourses of Donald Trump. - Journal of Language and Politics, kd 16, nr 4, lk 619-639.

Oreskes, Naomi, Conway, Erik M. 2010. Merchants of Doubt. New York: Bloomsbury Press.

Pi ir i mä e, Eva 2008. Keeleline pööre. - Keel ja Kirjandus, nr 8-9, lk 589-603.

Pinker, Steven 2018. Enlightenment Now. The Case for Reason, Science, Humanism, and Progress. New York: Penguin.

Proctor, Robert N. 1995. Cancer Wars: How Politics Shapes What We Know and Don't Know About Cancer. New York: Basic Books.

Prozorov, Sergei 2019. Why is there truth? Foucault in the age of post-truth politics. - Constellations, kd 26, nr 1, lk 18-30.

Rheind orf, Markus 2019. Revisiting the Toolbox of Discourse Studies. New Trajectories in Methodology, Open Data and Visualization. Cham: Palgrave Macmillan.

Ric o e ur, Paul 1977. Freud and Philosophy. Tlk Denis Savage. New Haven: Yale University Press.

Sokal, Alan, Bricmont, Jean 1998. Intellectual Impostures: Postmodern Philosophers' Abuse of Science. London: Profile Books.

van Dijk, Teun A. 2005. Ideoloogia: multidistsiplinaarne käsitlus. Tlk Merit Karise. Tartu: Tartu Ülikooli Kirjastus.

Wodak, Ruth (toim) 2013. Critical Discourse Analysis. Kd 1: Concept, History, Theory. Sage: London.

Raili Marling (snd 1973), PhD, Tartu Ülikooli maailma keelte ja kultuuride kolledži anglistika professor (Lossi 3, 51003 Tartu), raili.marling@ut.ee 


\section{Situated knowledge in the post-truth era}

Keywords: discourse analysis, post-truth, post-critique, postmodernism

Postmodernism and situated truths have been named among the creators of the post-truth world in both academic texts and mainstream media. Discourse studies is one of the disciplines associated with situated truths. That label covers, on the one hand, theoretical analyses inspired by the work of Michel Foucault and, on the other hand, the subfield of linguistics that studies contexualised language use. While critics habitually target discourse theory, the present think piece asks whether we could use empirically grounded discourse analysis to study the posttruth condition. The focus is on Johannes Angermüller's programme of discourse studies, inspired by science and technology studies. For Angermüller, discourse is a situated practice in which members of discourse communities linguistically construct and deconstruct truths. Instead of trying to identify a truth that is not influenced by society he proposes a reflexive study of competing truths. This far critical discourse analysis has sought to unmask truths it considers false. Angermüller believes that we should use the same theoretical and methodological tools to study what we consider true and false. The soft relativism of his approach accepts epistemic relativism, according to which discourses grow out of a specific context, but not the belief that all discourses offer an equally valid representation of reality, as each context possesses criteria for distinguishing facts and opinions. Angermüller's programme is one solution for using the empirical potential of discourse analysis for the study of the post-truth world.

Raili Marling (b. 1973), PhD, University of Tartu, Professor at the Department of English Studies (Lossi 3, 51003 Tartu), raili.marling@ut.ee 